\title{
The Adoption of Management Accounting Practices in Malaysian Small and Medium-Sized Enterprises
}

\author{
Kamilah Ahmad ${ }^{1}$ \\ ${ }^{1}$ Faculty of Technology Management and Business, University of Tun Hussein Onn Malaysia, Johor, Malaysia \\ Correspondence: Kamilah Ahmad, Faculty of Technology Management and Business, University of Tun Hussein \\ Onn Malaysia, Johor, Malaysia. E-mail: kamilah@uthm.edu.my
}

Received: October 10, 2013

Accepted: October 31, 2013 Online Published: December 29, 2013

doi:10.5539/ass.v10n2p236

URL: http://dx.doi.org/10.5539/ass.v10n2p236

\begin{abstract}
This paper provides empirical evidence on the adoption of a broad range of management accounting practices in Malaysian small and medium-sized enterprises (SMEs) in the manufacturing sector. Data collected from a postal survey of 160 accountant managers are used to facilitate the study. The results indicate that the traditional MAPs such as conventional budgeting, traditional costing and financial performance measures are widely used by the respondents. The results also show that a significant number of respondents have adopted one or more measures both financial and non-financial but the reliance on financial measures is greater than for non-financial measures. The main non-financial measures frequently used by respondents are on-time delivery, number of customer complaints, defect rate and manufacturing lead time. These findings suggest that respondents, who use non-financial performance measures, are more internal-process and customer focused rather than employee focused. Further the recently developed management accounting techniques such as ABC, non-financial performance measures particularly on employees-oriented measures, decision support analysis and strategic management accounting are only adopted by the minority of the respondents. The respondents also indicated a low extent of use of all investment appraisal techniques in their decision making process. The finding suggests that given the relatively small size of the responding firms and due to some constraints, it is unlikely for the SMEs to adopt a comprehensive MAP in their firms.
\end{abstract}

Keywords: management accounting practices, management accounting techniques, small and medium-sized enterprises (SMEs), manufacturing sector, Malaysia

\section{Introduction}

In the current globalised business economy, many small and medium-sized enterprises (SMEs) struggle for survival. There are many reasons for the discontinuity of business among SMEs besides rapidly changing market conditions. These include lack of adequate working capital, poor management skill and inadequate use of essential business and management practices. The use of management practices which can provide crucial information to the management is vital to ensure the effectiveness and efficiency of the business. One of the established practice in organisations; management accounting practice which comprises financial and non-financial information is one of the important management information system that should be utilised by the SMEs. Hopper, Koga \& Goto (1999) in their research among Japanese SMEs, argued that a failure to adopt management accounting practices (i.e. cost management systems) in a comparable way to their larger counterparts and, at the margins, to experiment with new forms of control that are more profit oriented may be a factor in the currently high failure rate of SMEs. This claim is consistent with Reid \& Smith (2002) who argued that efficient information-processing plays a vital role in successful smaller enterprises.

Thus, management accounting information has an important part to play with respect to planning, monitoring, and controlling of the activities of SMEs. Nandan (2010) who argued that like larger firms SMEs also require adequate and sophisticated management accounting techniques and systems to better manage scare resources and enhance the firm's values. Although SMEs may have some constraints in utilising fully management accounting practices due to their relatively small size and limited resources, like larger firms SMEs face similar forms of complexities, uncertainties and are more prone to failures. Therefore the need for strategic, accurate and reliable managerial information which is largely provided by management accounting system is equally significant for SMEs. In this regard, management accounting practices assume a potentially important function for SMEs. 
Despite the economic importance of SMEs around the world, there is a dearth of research regarding the use of management accounting among SMEs. Researches into management accounting among SMEs such as by Hopper et al. (1999); Jarvis, Kitching, Curran, \& Lightfoot (2000); Marriott \& Marriott (2000); Reid \& Smith (2002) and Sousa, Aspinwall, \& Rodrigues (2006) are still fragmented and focused on a different aspects of management accounting. Therefore there is only a few pieces of information regarding the use of MAPs in SMEs have been found in the literature. Mitchell \& Reid (2000) argued that, this situation is caused by the belief that empirical management accounting research designed to investigate technical innovation and development being concentrated on larger enterprises to the exclusion of smaller firms where the expertise and capacity to innovate in management accounting is less likely to exist. Therefore this position inevitably skews research towards larger entities. This claim is evidenced by the series of literatures examining the use of management accounting practices since three decades ago. For example research by Scarbrough, Nanni, \& Sakurai, 1991; Bright, Davies, Downes, \& Sweeting, 1992; Drury, Braund, Osborne, \& Tayles, 1993; Anderson \& Rohde, 1994; Innes \& Mitchell, 1995 Chenhall \& Langfield-Smith, 1998; Abdel-Kader \& Luther, 2006 focused on the use of management accounting among large firms in the developed countries. Whereby a substantial body of research investigating current management accounting practices in large organizations from developing countries was conducted by Ghosh \& Kai Chan, 1997; Joshi, 2001; Szychta, 2002; Islam \& Kantor, 2005; Wu, Boateng, \& Drury, 2007; El-Ebaishi, Karbhari, \& Naser, 2003; Van Triest \& Elshahat, 2007; Frezatti, 2007; Leftesi, 2008; and Nimtrakoon, 2009. Therefore the paucity of research into the use of management accounting practices among SMEs motivates this research. This paper contributes towards filling the gap in the literature by taking Malaysia as a case study. Malaysia is one of the countries that emphasizes heavily on SMEs sector for generating the national economy. The next subsection provides some details of Malaysian SMEs.

\subsection{SMEs Sector in Malaysia}

SMEs make up the vast majority of the business population in most countries in the world therefore they constitute a vital force in modern information-based economies (Mitchell \& Reid, 2000). In Malaysia the SMEs population comprises approximately 99 per cent of all Malaysian businesses (DOS (Note 1), 2005). This sector has contributed substantially to the Malaysian Gross Domestic Product (GDP) and total exports as well as has attracted foreign direct investment (FDI) to the country. As such this sector is considered as one of the main players in generating economic growth and in creating employment opportunity in Malaysia.

The role of this sector in the Malaysian economy became significant after the 1990s especially after the Asian Crisis in 1997-1998 and the series of other financial crisis which happened later in the twentieth century. In response to the instability and uncertainty in modern economy, the country learnt not to be overly dependent on the foreign direct investment (FDI) and used SMEs as a new mechanism for generating the growth of its economy (Aris, 2007). There has been active involvement of the Malaysian government in protecting and developing SMEs sector in Malaysia. The global financial crisis which had a severe impact on SMEs where the tightening of credit had caused the SMEs to struggle with insufficient working capital gave a big challenge for SMEs. In response, the Malaysian government introduced financial stimuli to help protect SMEs from the full brunt of the global financial crisis and place them on the track to recovery. The Malaysian government has also put up clear policies, strategies and implementation matrixes to develop this sector through an integrated approach. For example in 9th Malaysia Plan (2006-2010), the principal SMEs policy strives for the development of a competitive, innovative and technologically strong SME sector, capable of meeting the increasing demands of globalization and intensifying competition (National SME Development Council, 2007). In consequences various initiatives have been set in motion to build the capacity and capability of SMEs. The development plan for SMEs is further documented in $10^{\text {th }}$ Malaysian Plan (2011-2015) where the focuses are to enhance innovation, financing support and support system for SMEs (Economic Planning Unit, 2010).

Although there have been efforts to improve the management and business methods in production and marketing, there is concern about a lack of exposure to management accounting practices among firms in this sector since there is no specific reference to the use of MAPs. As SMEs sector is expected to remain as one of the main interest in Malaysian future economic development plan, it is worth investigating this sector from the aspects of management accounting practices.

\section{Literature Review}

There have been allegations about a lack of relevance of management accounting to managerial needs, especially in modern manufacturing, and about the existence of a gap between management accounting theory as portrayed in textbooks and management accounting in practice (Drury et al., 1993). The primary contention of these critiques was that management accounting fails to respond to developments in the technological and competitive 
environment, with the result that internal accounting information is frequently inaccurate and misleading (Drury et al., 1993). For example, Johnson \& Kaplan (1987) in their book 'Relevance Lost: The Rise and Fall of Management Accounting' claimed that as management accounting had not changed since the early part of the twentieth century, it had lost relevance by failing to provide relevant information for managerial needs. In response to these concerns, a range of remarkable innovations in management accounting has emerged. The more contemporary management accounting combines both financial and non-financial information and take an explicit strategic focus (Chenhall \& Langfield-Smith, 1998). This can be seen, for example in the design of activity-based costing (ABC), strategic management accounting (SMA) and contemporary performance measurement systems such as balanced scorecard (BSC). With this regard, more empirical researches have emerged in further years to investigate the current practices of management accounting in real organizations.

A number of studies have researched the adoption of management accounting practices in developed countries such as in Japan, U.S, U.K, other Europe countries and Australia (see for example Drury et al., 1993; Abdel-Kader \& Luther, 2006; Shields, Chow, \& Kao, 1991; Scarbrough et al., 1991; Chenhall \& Langfield-Smith, 1998; Wijewardena \& De Zoysa, 1999; Hyvo“ nen, 2005). In developing countries comparable empirical studies did not emerge until the mid-1990s. Example include: Firth (1996); Ghosh \& Chan (1997); Joshi (2001); Phadoongsitthi (2003); and El-Ebaishi et al. (2003). While these studies found the real management accounting practices in larger organizations, studies in smaller firm or SMEs is still lacking. According to Mitchell \& Reid (2000) empirical management accounting research, particularly that designed to investigate technical innovation and development, has been concentrated on the larger enterprise. When change and novelty has been the target of researchers, they have not pursued their aim in small firms where the expertise and capacity to innovate in management accounting is unlikely to exist. This situation creates a challenge into the study of management accounting practice in smaller enterprises or SMEs.

Limited examples of research into MAPs in SMEs in developed countries exist. For example, Drury et al. (1993) found that small businesses generally reported using more simplistic techniques, and the use of techniques such as $\mathrm{ABC}$, sensitivity analysis, market research and advanced quantitative techniques tended to be limited to the larger business units. This suggests that the gap between management accounting theory and practice may be particularly wide for small businesses. Similarly, Gunasekaran, Marri, \& Grieve (1999) in the U.K found that $\mathrm{ABC}$ has received little attention from SMEs in spite of the fact that it may have an important role to play in improving the competitiveness of SMEs.

Marriott \& Marriot (2000) revealed that all the 15 respondents in their study used computers for the preparation of management accounting information, but usually not to their full potential. The financial awareness of owner-managers varied considerably. The study concluded that there appears to be significant potential for accountants to expand the management accounting services they provide to smaller companies, especially to the interpretation of ratios and graphs of firms financial information.

Later, Reid \& Smith (2002) in a study of UK SMEs found that only a minority of small firms, typically around a third, set budgets; that payback was the most frequently applied investment appraisal technique and that the management accounting system (MAS) in a small firm has a significant effect on the operation and performance of the business. The impact of the MAS was greatest in those firms which are struggling to survive, where it can be used to monitor finances daily and can help to identify trends in key variables. Firms where financial performance is satisfactory, but static, tend to place less importance on the provision of management accounting information. Jarvis et al. (2000) stated that research has shown that small firms in the UK pursue a range of goals. It was, therefore, not surprising to find that owner-managers of small firms used a variety of measures and indicators to assess business performance. While cash flow indicators were considered to be critical, profit measures were found to be less important than conventional views suggest.

McChlery, Meechan, \& Godfrey (2004) investigated the scope of the financial management systems (including MAPs) operating within small firms. They found that management accounting systems did not have the same level of use as financial accounting overall with the former having a reduced uptake compared to the latter. They also found that smaller businesses were most likely to be dissatisfied with their management accounting systems. In a later study, Sousa et al. (2006) determined the current state of knowledge related to performance measures and their degree of implementation in SMEs in the U.K. Overall, financial measures were the most widely used, while innovation and learning measures were rated less important and were less used. The most important performance measures were not consistent with criteria to win new orders. However, the low response rate of the survey precludes generalisation of the findings.

In Europe, Kraus, Harms, \& Schwarz (2006), who examined strategic planning and performance in Austrian 
smaller enterprises, found that planning formalization has a positive and highly significant impact on the probability of belonging to a group of growth firms, whereas other aspects of strategic planning (time horizon, strategic instruments, and control) did not contribute to performance.

In U.S. Demong \& Croll (1981) concluded that although most U.S. small businesses started without a cost accounting system, its usefulness became quickly apparent to the owner/managers. A well-designed cost accounting system with its budgets, standard costs and break-even analyses will enable managers to make better decisions. Demong \& Croll (1981) suggested that all firms within the same industry will not require the same things from a cost accounting system. The larger firms will need a more sophisticated system to enable them to make frequent decisions on the prices and costs of their products. A smaller firm may only need a basic budget and some standard cost figures for their more infrequent pricing and cost decisions. In any case, all firms should have basic cost accounting systems with budgets and standard costs which can be used for planning and control. This or any system should be easy to use, understand, and maintain. In addition, it should be flexible and cost effective. Mcintyre \& Icerman (1985) studied the use of the accounting rate of return (ARR) by U.S small businesses and provided evidence of the nature and magnitude of errors that result from using the ARR for investment decisions. The results show that the ARR often produces substantial errors, and its use may be misleading. Small businesses are encouraged to take advantage of recent advances in technology which place IRR calculations within reach of any business involved in investment analysis.

In Japan a survey of cost accounting in SMEs was undertaken by Hopper et al. (1999). The results indicate that costing systems in Japanese SMEs were similar to those of larger Japanese firms. Costing systems and cost management practices though not uniform, emphasized simple routine accounting. They were not used extensively for decision-making or performance evaluation. However, sophisticated detailed processes of cost management, which often centered on engineering and quality control, were the norm.

In Malaysia many research has been undertaken in this area in respond to the Malaysian surge of interest in SMEs. However research into Malaysian SME is still fragmented. This situation is consistent with claims by Sulaiman \& Hashim (1999) and Boocock \& Wahad (1997) who indicated that information on SMEs in Malaysia is still narrow, inadequate, inconsistent and not easily available. Thus this study makes significant implication by providing new empirical evidence to the body of knowledge regarding the use of management accounting practices among SMEs.

The remainder of the article is structured as follows. In the section the research method is presented. The fourth section contains a discussion of the survey results. A comparison is made between findings from the current studies and those of prior surveys. Conclusions and implications for future research are presented in a final section.

\section{Method}

A survey was administered to 1,000 Malaysian manufacturing firms in SMEs sector. The firms were selected from the Federation of Malaysian Manufacturers (FMM). This source, although not comprehensive, provides detailed information about SMEs in the manufacturing sector. The sample was mailed with the first survey comprising a cover letter, questionnaire and a reply paid envelope. To encourage completion of the questionnaire, participants were promised a summary of the results and informed that their responses were anonymous. A month after the first mailing, 87 replies were received. A second and third mailing was used to increase the responses rate. At the end of the process a total of 176 questionnaires were received giving a response rate of $17.6 \%(176 / 1000)$. Of these 16 were unusable for the following reasons: the firm was too small, had ceased operation, or was from another sector; the questionnaire had not been completed; and the firm did not want to take part in the survey.

Hence, 160 usable questionnaires were received which equal to the net usable response rate of $16.1 \%(160 / 993)$ (Note 2). The usable response rate received in this survey is marginally better than the expected response rate of between $12 \%$ and $15 \%$. An expectation based on past response rates achieved by academic surveys of this type of population. Hence, it can be concluded that the usable response rate is considered acceptable and sufficiently large for analysis.

To examine for non-response bias, the responses from the first $30 \%$ of returns and those from the last $30 \%$ were compared, to test if responses differed between the two groups. The tests on profile of respondents as well as the use and the extent of management accounting practices were undertaken using chi-square and Mann-Whitney $\mathrm{U}$ non-parametric test. No differences were identified, providing some support for the absence of a non-response bias. 


\section{Survey Results and Discussion}

\subsection{Profile of Respondents}

Profile information relating to the respondents was collected to gain an overall overview of respondents. Four questions were asked and covered the number of years that the business had been in operation, the type of manufacturing activities; the number of employees; and annual sales turnover. This information is helpful for understanding the background of respondents and also for providing data for further statistical analysis. Table 1 presents the information for the 160 responding firms.

Table 1. Profile of the responding firms

\begin{tabular}{lll}
\hline Profile of firms & Frequency & Percent \\
\hline Years of operations/business & 2 & 1 \\
1-3 years & 17 & 11 \\
4-10 years & 141 & 88 \\
More than 10 years & 160 & 100 \\
Total & & \\
Manufacturing activities & 3 & 2 \\
Furniture & 26 & 17 \\
Food and beverages & 5 & 3 \\
Non-metallic products & 15 & 10 \\
Basic metals & 16 & 10 \\
Rubber and plastic & 30 & 19 \\
Chemicals \& chemical products & 63 & 40 \\
Others & 158 & 100 \\
Total & & \\
Number of employees & 50 & 31 \\
5-50 & 110 & 69 \\
$51-150$ & 160 & 100 \\
Total & & \\
Annual sales turnover & 2 & 1 \\
less than RM250 000 & 7 & 4 \\
RM250 000 to RM1.0 million & 20 & 13 \\
RM1.0 to RM5.0 million & 24 & 15 \\
RM5.0 to RM10.0 million & 73 & 45 \\
RM10.0 million to RM25.0 million & 34 & 22 \\
More than RM25.0 million & 160 & 100 \\
Total & & \\
\hline
\end{tabular}

The results show that an overwhelming majority of the firms (88\%) have been in business for more than 10 years. This is followed by respondents who have been in the business between 4-10 years (11\%). In contrast, the numbers of newly operating firms (1-3 years) are only $1 \%$ of respondents. Thus, the vast majority of the responding firms are established businesses that might reasonably be expected to use management accounting techniques and have developed management accounting systems that are suitable for their business needs. The findings may arise from the use of the directory as a population source, as firms may only seek a directory entry when established rather than on formation.

In general, the manufacturing activities of responding firms are concentrated in chemicals and chemical products $(19 \%)$ and food and beverages (17\%). The next principal areas are basic metals and rubber and plastic with around $10 \%$ of respondents in each of them. The lowest responding activity areas are furniture and non-metallic products with less than $5 \%$ of respondents.

The response rate among medium firms is disproportionally higher than for small firms. The result indicates that 
the population is heavily biased towards firms with over 50 employees $(69 \%)$ with only $31 \%$ of responding firms having 50 or less employees. This concentration of respondents in larger firms is also indicated by the information gathered on the annual sales turnover of the respondents Almost half of the responding firms reported annual sales from RM10 to RM25 million. This is followed by annual sales below RM10 million (33\%). The smallest group with less a quarter of total respondents is indicated by firms with annual sales turnover more than RM25 million.

\subsection{Use of Management Accounting Practices}

The questionnaire first ascertained whether or not the respondents used each particular practice in their firms. If yes, further enquiry was then made into the extent of the use based on a five-point Likert scale. Table 2 details the extent to which there was any use of the designated management accounting practices. The table splits the data into three main columns; two based on category of the firm (small or medium) and the third the total result. The rank of MAPs by adoption is included at the end of each column to provide an overview of the results.

Table 2. The results relating to the use of management accounting practices and the ranking of practices

\begin{tabular}{lllllllllll}
\hline & \multicolumn{3}{l}{ Small } & \multicolumn{3}{c}{ Medium } & \multicolumn{5}{c}{ Total } \\
& $\begin{array}{l}\text { No } \\
(\%)\end{array}$ & $\begin{array}{l}\text { Yes } \\
(\%)\end{array}$ & Rank & $\begin{array}{l}\text { No } \\
(\%)\end{array}$ & $\begin{array}{l}\text { Yes } \\
(\%)\end{array}$ & Rank & $\begin{array}{l}\text { No } \\
(\%)\end{array}$ & $\begin{array}{l}\text { Yes } \\
(\%)\end{array}$ & Rank \\
\hline Costing system & 24 & 76 & 2 & 14 & 86 & 1 & 17 & 83 & 1 \\
Budgeting system & 36 & 64 & 3 & 19 & 81 & 2 & 24 & 76 & 3 \\
Performance evaluation system & 22 & 78 & 1 & 20 & 80 & 3 & 21 & 79 & 2 \\
Decision support system & 54 & 46 & 4 & 28 & 72 & 4 & 37 & 63 & 4 \\
Strategic management accounting & 65 & 35 & 5 & 42 & 58 & 5 & 49 & 51 & 5 \\
\hline
\end{tabular}

Notes: Total number of responses for small firm $=50$; medium $=110$ and total firm: 160

Table 2 shows that medium sized firms have a higher adoption of all MAPs as compared to small sized firms. This is especially true in the use of decision support system and SMA where usage is $26 \%$ and $23 \%$ higher respectively for medium-sized firms. The greater use of these more sophisticated techniques by medium firms probably reflects the increased complexity of business activity in medium firms especially for the firms who deploy modern technologies and new management processes (Abdel-Kader \& Luther, 2008). Besides, medium firms are usually more capital intensive and this additional investment in their business possibly leads to greater risk aversion which implies a more analytical approach to decision-making and the development of business strategy. A further reason for medium firms being relatively high adopters of recently-developed MAPs is their relatively greater access to resources to experiment with administrative innovations. Chenhall \& Langfield-Smith (1998) noted that an impediment to implementing innovative management accounting systems is the prohibitive costs. Therefore the above three reasons might contribute to the higher use of sophisticated accounting systems among medium firms.

Findings also show that medium firms employ budgetary systems more frequently. Explanations for this can be based again on size of the firms. Larger organizational firms usually have more complex tasks thus these firms require a system that can help them to achieve the common purpose and coordinate activities. Budgeting is one of such systems, thus this may explain why medium firms have a higher rate of adoption of budgeting system than small firms. In contrast, there is a little variation in the usage of the other two management accounting practices; performance evaluation system (2\%) and costing system (10\%). This finding suggests that monitoring business performance and the availability of cost information are equally important to both categories of firms.

In terms of ranking, the most popular practice is performance evaluation within the small firms and costing system in medium firms. However for all respondents, costing system is the most widely used practice. In contrast, the least favoured practice is SMA for both groups with only half of total respondents making any use of this practice suggesting that this technique is not yet practical for many small and medium firms in Malaysia. It can be concluded that within the different size of firms, there is little difference in the ranking of adoption rates of management accounting practices between small and medium companies. 


\subsection{Discussion on Extent of the Use of MAPS}

The previous section has discussed in detail the extent of use of five major parts of management accounting practices. This section will further investigate the frequency of use of 45 specific management accounting techniques under the broad headings discussed in the above section. The extent of the use of management accounting was examined by requiring the respondents, who responded yes to using broadly classified management accounting practices, to indicate the frequency of use of a range of detailed management accounting practices using a five-point scale (where S1 indicates 'never' and S5 is 'very frequently').

Data in Table 3 shows the results for 45 ranked techniques of management accounting practices. To help the discussion, those techniques are divided into four levels (Level 1, 2, 3 and Level 4) based on descending order of mean value. Level 1 put together the first 10 techniques which are classified as relatively high extent of use. Level 2 lays the next 10 techniques which are classified as relatively moderate extent of use, followed by level 3 for the next 10 techniques as low extent of use. The remaining 15 techniques, relatively lowest extent of use are put in level 4. This classification provides a simple "high-low" snapshot from the highest extent of use (Level 1) to the lowest extent of use (Level 4). The discussion for these data is made accordingly in the following subsections.

Table 3. Ranking and descriptive statistics of management accounting techniques

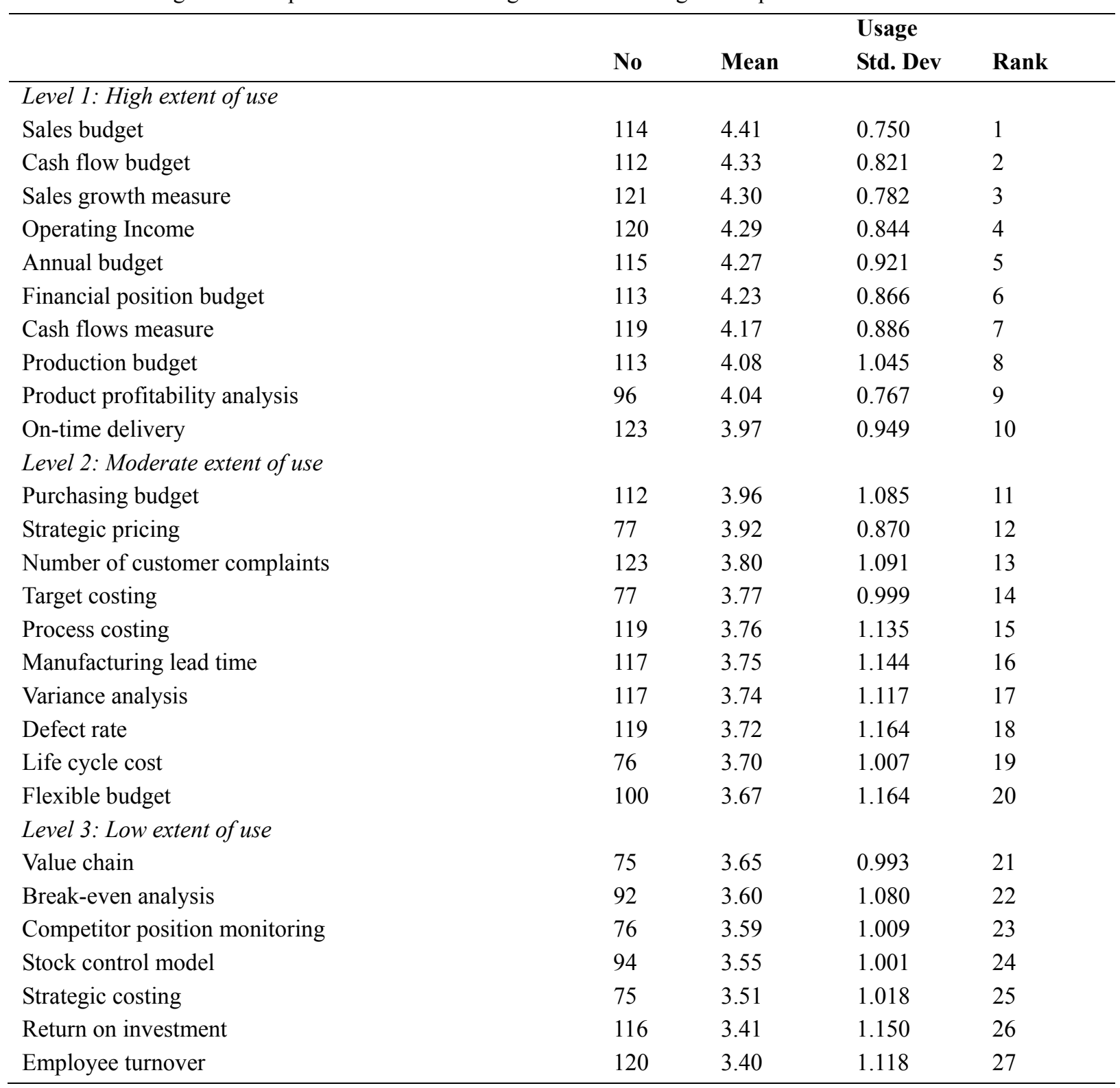




\begin{tabular}{lllll}
\hline & & & Usage \\
& No & Mean & Std. Dev & Rank \\
\hline Customer profitability analysis & 92 & 3.39 & 1.037 & 28 \\
Monthly budget & 96 & 3.38 & 1.416 & 29 \\
Absorption costing & 90 & 3.38 & 1.402 & 30 \\
Level : Lowest extent of use & & & & \\
Survey of customer satisfaction & 123 & 3.37 & 1.104 & 31 \\
Payback & 92 & 3.37 & 1.174 & 32 \\
Absentee rates & 119 & 3.36 & 1.103 & 33 \\
Incremental budgeting & 95 & 3.24 & 1.327 & 34 \\
Job costing & 103 & 3.21 & 1.218 & 35 \\
Continuous budget & 93 & 3.19 & 1.296 & 36 \\
Variable costing & 90 & 3.19 & 1.141 & 37 \\
Accounting rate of return & 90 & 3.17 & 1.229 & 38 \\
Net present value & 91 & 3.12 & 1.228 & 39 \\
Internal rate of return & 91 & 3.04 & 1.219 & 40 \\
Batch costing & 105 & 2.90 & 1.362 & 41 \\
Activity-based costing & 91 & 2.87 & 1.439 & 42 \\
Number of warranty claims & 117 & 2.80 & 1.315 & 43 \\
Contract costing & 103 & 2.75 & 1.319 & 44 \\
Zero-based budgeting & 80 & 2.38 & 1.226 & 45 \\
\hline
\end{tabular}

\section{Level 1: High extent of use}

Table 3 presents the first nine highest ranks in level 1 are comprised of financial-based management accounting techniques. Techniques under budgeting system dominate the ranks. Meanwhile on-time delivery is ranked at $10^{\text {th }}$ and become the only non-financial-oriented management accounting technique that is highly used by the respondents. The results recommend that the financial-oriented management accounting techniques (budgeting techniques, financial performance measures and product profitability) which represent the traditional management accounting practices are widely used by the respondents. Despite being criticised of having some shortcomings, traditional management accounting practices appear to remain relevant among Malaysian SMEs in manufacturing sector.

A highly use of financial-oriented management accounting techniques is consistent with many previous researches. For example, Chenhall \& Langfield-Smith (1998) reported budgeting for planning financial position together with other budgeting such as budgeting for cash flows and controlling cost are among the highest rank in Australia manufacturing firms whereby the product profitability are in the $10^{\text {th }}$ rank which is similar with the result of this study. Similar results are also revealed by Luther \& Longden (2001) who reported the high means of use in traditional budgeting in Africa. In the U.K, Abdel-Kader \& Luther (2006) who studied the use of MAPs among British food and drinks industry reported budgeting for planning, controlling cost, performance evaluation based on financial measures and product profitability analysis were in the top four of the rank. The results are also consistent in many studies in other countries such as Firth (1996) in China; Ghosh \& Chan (1997) in Singapore; Pierce \& O’Dea (1998) in Ireland; Joshi (2001) in India; Phadoongsitthi (2003) in Thailand and Hyvonen (2005) in Finland.

\section{Level 2: Moderate extent of use}

A moderate extent of use is comprised by the techniques under non-financial performance measures, costing system and strategic management accounting. Purchasing budget is ranked at $11^{\text {th }}$ which is still implying the importance role of budgeting system among respondents. The number of customer complaints, manufacturing lead time and defect rate are non-financial performance measures that are frequently used by the respondents. The results suggest that the current management accounting techniques begin to receive attention among Malaysian SMEs in the manufacturing sector.

Next the results show that process costing is the most widely employed cost collection method as opposed to batch costing, contract and job costing. The results suggest that the majority of the respondents manufacturing 
operations are in process-based activities. Besides, the finding indicates that traditional costing is commonly used among the respondents as opposed to ABC.

Surprisingly three techniques under strategic management accounting, strategic pricing, target costing and life cycle cost are frequently used techniques among respondents. The result suggests smaller businesses also place heavy consideration when it comes into strategic pricing and costing. This practice will ensure their long term competitiveness in the market. Further variance analysis which is one of traditional management accounting ranked at number $17^{\text {th }}$ indicating the widely use of another traditional management accounting approach.

Overall the finding suggests that some of the respondents have been practising not only traditional management accounting but also strengthening the practices with the use of certain recently-developed management accounting techniques such as non-financial performance measures and certain elements of strategic management accounting.

Prior studies also revealed that the use of nonfinancial measure has received increased attention among firms. For example, in the U.K., Bhimani (1993) reported that executives were receptive to the use of non-financial indicators. In a survey by Dugdale (1994), non-financial measures ranked fourth out of 30 in importances. In Australia, a survey by Chenhall \& Langfield-Smith (1998) showed that most non-financial measures were included in the high and medium adoption categories showing that both financial and nonfinancial measures play an important role among Australian manufacturing firms. The growing attention on nonfinancial measure is also can be found in other studies such as Bruggeman, Slagmulder, \& Waeytens (1996) in Belgium and Dean Dean, Joye, \& Blayney (1993) in Australia.

The moderate use of three techniques of strategic management accounting practices is quite a surprise. This result suggests that the respondents have implemented some sort of strategic approaches in their firm especially in term of pricing and costing to better compete in a global and competitive market. A moderately high extent of use of strategic pricing is consistent with finding by Guilding, Cravens, \& Tayles (2000). However, Guilding et al. (2000) reported that target costing is at the lowest rank. Similarly Chenhall \& Langfield-Smith (1998) also found that target costing has a relatively low rate of adoption among Australian firms (rank 27) as opposed to the result of this study which is at rank 14. It may be that, the result has a little bias where perhaps the response reflects a desire by those answering to overstate their use of management accounting techniques to show a positive response for the survey. Another possible contributory reason is that some of the respondents might not understand the term and this led them to answer yes in case they did use it.

\section{Level 3: Low extent of use}

Level 3 presents ten techniques of relatively low extent of use. The data presented in this level is mainly comprised of techniques under performance evaluation system, decision support analysis, and strategic management accounting. The findings propose that the sophisticated management accounting techniques which require the firms to do further analysis on cost, customer, employee and competitors receive little attention among respondents. This result implies that smaller firms do not require additional detailed analyses due to the relevancies of those techniques to their limited operating environment and activities. For example the respondents are less frequently use customer profitability analysis as opposed to product profitability analysis which is far more suitable to the nature of their firm's activities. Similarly, the uptake of three strategic management accounting techniques (value chain, competitor position monitoring and strategic costing) is low among respondents. The result is expected due to the size of the responding firms. The result mirrors Guilding et al. (2000), who in a multi-country study reported low usage rates for these techniques.

\section{Level 4: Lowest extent of use}

Data in level 4 presents management accounting techniques at the end of the scale, (relatively lowest extent of use). Unsurprisingly given the likely lack of repeated major investment decisions in firms of smaller size, the level of use of the long run investment appraisals is low. The result suggests that the capital investment techniques are infrequently used by respondents to this study. The low use of long term analysis particularly for capital budgeting is similar with the result by Dugdale (1994) who reported that capital budgeting received a relatively low rating for benefits received, ranking only 22 nd out of 30 management accounting techniques. In contrast to these results, there are several surveys have reported that the use of capital budgeting analysis is widespread (Klammer, Koch, \& Wilner, 1991; Drury et al., 1993; Carr \& Tomkins, 1996; Chenhall \& Smith, 1998). Chenhall \& Langfield Smith (1998) found out that techniques concerned with the long-term were capital budgeting tools are ranked 2. It is noted that the lowest extent of use of long-term financial appraisal is actually fit the nature of small firms. Since the sample of this study within a relatively small size firms, the use sophisticated analysis is rather low. Thus this is not a surprising result. 
The findings also recommend that batch, contract, job costing are the least used techniques of cost collection system as opposed to process costing. Meanwhile both variable costing and ABC turns out to be the least choices of type of costing system as against to absorption costing. The low use of the recently-developed costing technique; $\mathrm{ABC}$ is not a surprising result because neither in this study nor in other studies reported a high extent use of this technique. For example, Chenhall \& Langfield-Smith (1998) found that the adoption of ABC as relatively low (ranked 38). Similarly, Phadoongsitthi (2003) reported this technique at rank $20^{\text {th }}$ which is relatively low. Meanwhile Abdel-Kader \& Luther (2006) in their study among British firm revealed that ABC was ranked 32 out of 38 MAPs.

Data in Level 4 also indicates the low use of the four nonfinancial performance measures (survey of customer satisfaction, absentee rates, and number of warranty claims). Customer satisfaction is little used perhaps because the respondents have already focused on number of customer complaints as a primary tool for evaluating their customer-based performance. This result suggests that at present, the responding firms are emphasizing on the selected nonfinancial performance measures especially on customer complaints and internal-oriented measures in measuring their business activities performance. The lower use of non-financial measures is consistent with prior research but may also be attributed to the size of the firms as it is difficult for smaller firms to employ as many performance measures as larger firms because of cost and other limitations. Besides as non-financial measures are more recently-developed measures, their adoption may not be as widespread as opposed to the traditional measures which have long been used by many firms. Thus these reasons might explain the low adoption of non-financial measures found in this study.

On the whole, the result in Table 2 provides strong indication that traditional management accounting (especially in conventional budgeting, traditional costing and financial performance measures) are well practised by responding firms as opposed to some recently-developed management accounting practices.

\section{Conclusion}

This research reports descriptive results obtained from 160 useable responses to a questionnaire sent to a sample of 1,000 Malaysian SMEs in the manufacturing sector enquiring as to the extent of their use of MAPs. Across the sample, all five categories of MAPs surveyed (costing, budgeting performance evaluation, decision support system and SMA) are adopted by the majority of responding Malaysian manufacturing firms. However if small firms are considered separately, only a minority utilised decision support systems and SMA. The results also show that the adoption rate for traditional management accounting techniques is higher for established practices (budgeting, performance evaluation and costing) than for more recently developed practices (decision support system and SMA). Results for all MAPs also indicate that a higher usage by medium sized firms as opposed to small firms. The most significant differences relate to the use of decision support system and SMA.

The study also investigated the specific extent of use by Malaysian SMEs of a range of specific management accounting techniques. Responses detailed the extent of use of 45 management accounting techniques grouped under the five broad headings for MAPs stated earlier. The results shows that process costing is the most widely used cost collection method, and absorption and variable costing are the most frequently applied costing techniques. The high use of process costing is consistent with the sectors that respondents were in. The majority of the respondents also indicate high use of full financial budgeting. Annual budgeting was the commonest timing for. In evaluating firm performance, most of the respondents indicated a high use of financial performance measures as opposed to non-financial measures. The most used among non-financial measures related to internal processes and customers, while those connected to employees are the least used. Techniques, listed under decision support system and strategic management accounting have rather a limited and lower frequency of use. Under the decision support system, the results show that product profitability analysis is used the most.

The findings produce some original results on the use of management accounting practices by Malaysian SMEs. The results suggest that in general, Malaysian SMEs and especially medium sized enterprises have widely adopted basic techniques of management accounting, for example costing; budgeting systems and performance evaluation measures. This prioritization of basic techniques of accounting and management accounting is reasonable and somewhat expected in a smaller business context. Furthermore since the respondents are based in a developing country, the employment of new management accounting skills, such as ABC, SMA and other modern techniques, would expect to be lower than for basic techniques as it is in developed countries. This view is in line with Chun et al. (1994) who claimed that Malaysian firms prefer to employ traditional management accounting systems to meet their needs for external and internal reporting purpose. Other research on developing countries such as Joshi (2001) in India; El-Ebaishi et al. (2003) in Saudi Arabia and Phadoongsitthi (2003) in 
Thailand also support this position. Joshi (2001) argued that the reasons of a low adoption of newly developed practices in Indian firms are the conservative attitude of Indian management, autocratic leadership, and long term orientation. Many Indian companies believe that it is quite expensive to adopt the new management accounting techniques particularly, for benchmarking. Lack of training and expertise in these areas are other possible reasons. Phadoongsitthi (2003) in Thailand supported the view by Joshi (2001) by stating that the reasons for such similarities of low adoption of newly developed management accounting practices between Thai and India is because both countries have cultural similarities like large power distance and low individualism group and both countries facing similar problems like the lack of training and expertise. Research in developed countries (see, for example, Chenhall \& Smith, 1998; Pierce \& O’Dea, 1998; Abdel-Kader \& Luther, 2006), although reporting an increasing usage of modern management accounting practices, agreed that basic or traditional management accounting practices are still dominant in most firms. It is argued that high acceptance of traditional techniques may be attributed to the fact that information on these measures is the most readily available as opposed to modern management accounting techniques. The sophisticated systems are not widely adopted in practice possibly due to the uncertainties, practicalities and costs involved in obtaining the information.

The results of the chapter also indicate some striking differences between the adoption level for newer techniques and conventional techniques. Interestingly this result is replicated in most previous literature (see for example, Holmes \& Nicholls, 1989; Hoque \& James, 2000; Lamminmaki \& Drury, 2001; Collis \& Jarvis, 2002; Al-Omiri \& Drury, 2007; Ismail \& King, 2007; Cadez \& Guilding, 2008; Abdel-Kader \& Luther, 2008) even though the population from which the target sample is drawn is unusual in terms of country size and the developing country context.

Therefore it is suggested that within Malaysian SMEs, there is extensive use of basic management accounting practices. Medium enterprises make greater use of management accounting practices in comparison to small firms. The study suggests that there is ample room to increase both awareness of and understanding of the importance of MAPs within SMEs since these practices are very important ingredients in the success of any organizations. The results indicated that traditional and financially oriented MAPs have high level of usage but the adoption of newly-developed management accounting practices remains patchy. Perhaps Malaysian policy makers could provide training in these techniques for entrepreneurs or future graduates in Malaysia.

This research has increased knowledge of MAPs in a SMEs context. Malaysia as a developing country has strived to move to parity with more developed economies, will find the research useful to provide relevant knowledge that can support efforts to enhance the performance of Malaysian SMEs. This study can be also a starting point for further investigations and analysis of MAPs among SMEs. In conclusion, the work presents new empirical evidence and explanations of the use of MAPs in SMEs and therefore makes a contribution to the awareness of management accounting in SMEs in Malaysia.

This study has certain limitations. First, the low response to the questionnaire survey potentially introduces non-response bias especially for small firm category. Hence the sample of small firms should be extended to achieve a valid set of responses. Secondly the nature of the dependence between traditional and sophisticated MAPs needs further investigation. The lower use of sophisticated MAPs raises the question of the conditions necessary to effectively implement these techniques within smaller firms. Again a qualitative case study approach would provide real insights that could not be gleaned from a questionnaire survey approach.

\section{References}

Abdel-Kader, M., \& Luther, R. (2006). Management accounting practices in the British food and drinks industry. British Food Journal, 108, 336-357. http://dx.doi.org/10.1108/00070700610661321

Abdel-Kader, M., \& Luther, R. (2008). The impact of firm characteristics on management accounting practices: A UK-based empirical analysis. The British Accounting Review, 40, 2-27. http://dx.doi.org/10.1016/j.bar.2007.11.003

Al-Omiri, M., \& Drury, C. (2007). A survey of factors influencing the choice of product costing systems in UK organizations. Management Accounting Research, 18, 399-424. http://dx.doi.org/10.1016/j.mar.2007.02.002

Anderson, S.W., \& Lanen, W. (1999). Economic transition, strategy and the evolution of management accounting practices: The case of India. Accounting, Organizations and Society, 24, 379-412. http://dx.doi.org/10.1016/S0361-3682(97)00060-3

Aris, N. M. (2007). SMEs: Building Blocks for Economic Growth. Department of Statistics: Malaysia, 1, 1-13.

Bhimani, A. (1993). Performance measures in UK manufacturing companies: The state of play. Management Accounting, 20-23. 
Boocock, G., \& Shariff, M. N. M. (2005). Measuring effectiveness of credit guarantee schemes: Evidence from Malaysia. International Small Business Journal, 23, 427. http://dx.doi.org/10.1177/0266242605054054

Bright, J., Davies, R. E., Downes, C. A., \& Sweeting, R. C. (1992). The deployment of costing techniques and $\begin{array}{lllll}\text { practices: A } & \text { UK study. Management Accounting, }\end{array}$ http://dx.doi.org/10.1016/S1044-5005(92)70011-0

Bruggeman, W., Slagmulder, R., \& Waeytens, D. (1996). Management accounting changes: The Belgium experience. In A. Bhimani (Ed.), Management Accounting: European Perspectives (pp. 1-30). Oxford: Oxford University Press.

Cadez, S., \& Guilding, C. (2008). An exploratory investigation of an integrated contingency model of strategic management accounting. Accounting, Organizations and Society, 33, 836-863. http://dx.doi.org/10.1016/j.aos.2008.01.003

Carr, C., \& Tomkins, C. (1996). Strategic investment decisions: The importance of SCM. A comparative analysis of 51 case studies in the UK, US and German companies. Management Accounting Research, 7, 199-217. http://dx.doi.org/10.1006/mare.1996.0012

Chenhall, R. H., \& Langfield-Smith, K. (1998). Adoption and benefits of management accounting practices: An Australian study. Management Accounting Research, 9, 1-19. http://dx.doi.org/10.1006/mare.1997.0060

Chun, L. S., Kassim, N. A. A., \& Minai, B. (1994). Are management accounting systems in Malaysia outmoded? Singapore Management Review, 55-67.

Collis, J., \& Jarvis, R. (2002). Financial information and the management of small private companies. Journal of Small Business and Enterprise Development, 9, 100-110. http://dx.doi.org/10.1108/14626000210427357

Dean, G. W., Joye, M. P., \& Blayney, P. J. (1993). Strategic management accounting survey: Overhead cost allocation performance evaluation practices of Australian manufacturers. The Accounting Review, 68, 426-427.

Demong, R. F., \& Croll, D. B. (1981). Cost accounting for the small business. American Journal of Small Business, 5, 48-60.

DOS. (2005). Census of Establishments and Enterprises. Profile of Small and Medium Enterprises. Department of Statistic: Malaysia.

Drury, C., Braund, S., Osborne, P., \& Tayles, M. (1993). A survey of management accounting practices in UK manufacturing companies. Chartered Association of Certified Accountants. UK.

Dugdale, D. (1994). Theory and practice: The views of CIMA and students. Management Accounting (UK), 56-59.

Economic Planning Unit. (2010). Tenth Malaysia Plan 2011-2015. EPU: Malaysia.

El-Ebaishi, M., Karbhari, Y., \& Naser, K. (2003). Empirical evidence on the use of management accounting techniques in a sample of Saudi manufacturing companies. International Journal of Commerce and Management, 13, 74-101. http://dx.doi.org/10.1108/eb047467

Firth, M. (1996). The diffusion of managerial accounting procedures in the People's Republic of China and the influence of foreign partnered joint ventures. Accounting, Organizations and Society, 21, 629-654. http://dx.doi.org/10.1016/0361-3682(95)00039-9

Frezatti, F. (2007). The economic paradigm in management accounting return on equity and the use of various management accounting artifacts in a Brazilian context. Managerial Auditing Journal, 22, 514-532. http://dx.doi.org/10.1108/02686900710750784

Ghosh, B. C., \& Chan, Y. K. (1997). Management accounting in Singapore-well in place? Managerial Auditing Journal, 12, 16-18. http://dx.doi.org/10.1108/02686909710155966

Guilding, C., Cravens, K. S., \& Tayles, M. (2000). An international comparison of strategic management accounting practices. Management Accounting Research, 11, 113-135. http://dx.doi.org/10.1006/mare.1999.0120

Gunasekaran, A., Marri, H. B., \& Grieve, R. J. (1999). Justification and implementation of activity based costing in small and medium sized enterprises. Logistics Information Management, 12, 386-394. http://dx.doi.org/10.1108/09576059910295869

Holmes, S., \& Nicholls, D. (1989). Modeling the accounting information requirements of small businesses. 
Accounting and Business Research, 19, 143-150. http://dx.doi.org/10.1080/00014788.1989.9728844

Hopper, T., Koga, T., \& Goto, J. (1999). Cost accounting in small and medium sized Japanese companies: An exploratory study. Accounting and Business Research, 30, 73. http://dx.doi.org/10.1080/00014788.1999.9728925

Hoque, Z., \& James, W. (2000). Linking balanced scorecard measures to size and market factors: Impact on organizational performance. Journal of Management Accounting Research, 12, 1-12. http://dx.doi.org/10.2308/jmar.2000.12.1.1

Hrisak, D. (1996). The controller as business strategist. Management Accounting, 78, 48-49.

Hyv"onen, J. (2007). Strategy, performance measurement techniques and information technology of the firm and their links to organizational performance. Management Accounting Research, 18, 343-366. http://dx.doi.org/10.1016/j.mar.2007.02.001

Innes, J., \& Mitchell, F. (1995). A survey of activity-based costing in the U.K.'s largest companies. Management Accounting Research, 6, 137-153. http://dx.doi.org/10.1006/mare.1995.1008

Islam, M., \& Kantor, J. (2005). The development of quality management accounting practices in China. Managerial Auditing Journal, 20, 707-724. http://dx.doi.org/10.1108/02686900510611249

Ismail, N. A., \& King, M. (2007). Factors influencing the alignment of accounting information systems in small and medium sized Malaysian manufacturing firms. Journal of Information Systems and Small Business, 1, $1-20$.

Jarvis, R., Kitching, J., Curran, J., \& Lightfoot, G. (2000). The use of quantitative and qualitative criteria in the measurement of performance in small firms. Journal of Small Business and Enterprise Development, 7 , 123-134. http://dx.doi.org/10.1108/EUM0000000006834

Johnson, H. T., \& Kaplan, R. S. (1987). Relevance Lost: The Rise and fall of Management Accounting. Boston, Massachusetts: Harvard Business School Press.

Joshi, P. L. (2001). The international diffusion of new management accounting practices: The case of India. Journal of International Accounting, Auditing and Taxation, 10, 85-109. http://dx.doi.org/10.1016/S1061-9518(01)00037-4

Klammer, T., Koch, B., \& Wilner, N. (1991). Capital budgeting practices-a survey of corporate use. Journal of Management Accounting Research, 1, 13-130.

Kraus, S., Harms, R., \& Schwarz, E. J. (2006). Strategic planning in smaller enterprises-new empirical findings. Management Research News, 29, 334-344. http://dx.doi.org/10.1108/01409170610683851

Lamminmaki, D., \& Drury, C. (2001). A comparison of New Zealand and British product-costing practices. The International Journal of Accounting, 36, 329-427. http://dx.doi.org/10.1016/S0020-7063(01)00106-6

Leftesi, A. (2008). The Diffusion of Management Accounting Practices in Developing Countries: Evidence from Libya. Ph.D Thesis, University Huddersfield, United Kingdom.

Luther, R. G., \& Longden, S. (2001). Management accounting in companies adapting to structural change and volatility in transition economies: A South African study. Management Accounting Research, 12, 299-320. http://dx.doi.org/10.1006/mare.2001.0163

Marriott, N., \& Marriott, P. (2000). Professional Accountants and the Development of a Management Accounting Service for the Small Firms: Barriers and Possibilities. Management Accounting Research, 11, 475-492. http://dx.doi.org/10.1006/mare.2000.0142

McChlery, S., Meechan, L., \& Godfrey, A. D. (2004). Barriers and catalysts to sound financial management systems in small sized enterprises. Research Executive Summaries Series CIMA, 1.

Mcintyre, E. V., \& Icerman, J. I. (1985). The accounting rate of return-Appropriate for small businesses? American Journal of Small Business, IX, 41-49.

Mitchell, F., \& Reid, G. C. (2000). Editorial problems, challenges and opportunities: The small business as a setting for management accounting research. Management Accounting Research, 11, 385-390. http://dx.doi.org/10.1006/mare.2000.0152

Nandan, R. (2010). Management Accounting Needs of SMEs and the Role of Professional Accountants: A Renewed Research Agenda. Journal of Management Accounting Research, 8, 65-77. 
National SME Development Council (NSDC). (2007). SME Annual Report 2007. Malaysia.

Nimtrakoon, S. (2009). Organization Strategy, Management Techniques and Management Accounting Practices: Contingency Research in Thailand. Ph.D Thesis, University of Hull, United Kingdom.

Phadoongsitthi, M. (2003). The role of management accounting in emerging economies: An empirical study of Thailand. Ph.D Thesis, University of Maryland, College Park.

Pierce, B., \& O’Dea, T. (1998). Management accounting practices in Ireland. The Irish Accounting Review, 35-66.

Reid, G. C., \& Smith, J. A. (2002). The bigger picture. Financial Management.

Scarbrough, P., Nanni, A. J., \& Sakurai, M. (1991). Japanese management accounting practices and the effects of assembly and process automation. Management Accounting Research, 2, 27-46. http://dx.doi.org/10.1016/S1044-5005(91)70025-5

Shields, M. D., Chow, C. W., \& Kao, Y. (1991). Management accounting practices in the U.S. and Japan: Comparative survey findings and research implications. Journal of International Financial Management \& Accounting, 3, 61-77. http://dx.doi.org/10.1111/j.1467-646X.1991.tb00091.x

Sousa, S. D., Aspinwall, E. M., \& Rodrigues, A. G. (2006). Performance measures in English small and medium enterprises: Survey results benchmarking. An International Journal, 13, 120-134.

Sulaiman, M., Wafa, A., \& Hashim, K. (2000). Strategic management in Malaysian SMEs: An empirical assessment. Malaysian Management Review.

Szychta, A. (2002). The scope of application of management accounting methods in Polish enterprises. Management Accounting Research, 13, 401-418. http://dx.doi.org/10.1006/mare.2002.0198

Van Triest, S., \& Elshahat, M. F. (2007). The use of costing information in Egypt: A research note. Journal of Accounting and Organizational Change, 3, 329-343. http://dx.doi.org/10.1108/18325910710820328

Wijewardena, H., \& De Zoysa, A. (1999). A comparative analysis of management accounting practices in Australia and Japan: An empirical investigation. The International Journal of Accounting, 34, 49-70. http://dx.doi.org/10.1016/S0020-7063(99)80003-X

Wu, J., Boateng, A., \& Drury, C. (2007). An analysis of the adoption, perceived benefits, and expected future emphasis of western management accounting practices in Chinese SOEs and JVs. The International Journal of Accounting, 42, 171-185. http://dx.doi.org/10.1016/j.intacc.2007.04.005

\section{Notes}

Note 1. The Department of Statistics Malaysia

Note 2. The usable response rate is calculated as follows: response rate $=$ (number of completed and returned questionnaires) divided by (Number of respondents in sample - (non-eligible and non-reachable respondents)

\section{Copyrights}

Copyright for this article is retained by the author(s), with first publication rights granted to the journal.

This is an open-access article distributed under the terms and conditions of the Creative Commons Attribution license (http://creativecommons.org/licenses/by/3.0/). 